\title{
Comparative Study between Oral Pregabalin versus Intravenous Low Dose Ketamine for Post-Operative Pain Management in Laminectomy
}

\author{
AHMED G. ARAKEEB, M.Sc.; ABDEL AZIZ H. EL BADAWY, M.D.; HODA A.A. EZZ, M.D. and \\ ASMAA F. AMER, M.D.
}

The Department of Anesthesiology and Surgical Intensive Care, Faculty of Medicine, Tanta University

\begin{abstract}
Background: Lumbar laminectomy is accompanied with significant post-operative pain. Preemptive analgesia is effective to reduce the magnitude and duration of post-operative pain.

Aim of Study: The aim of this study is to compare the efficacy of oral pregabalin versus IV low dose ketamine for postoperative pain management in patients undergoing elective single level lumbar laminectomy.

Material and Methods: This prospective double blind randomized controlled study was carried out on 105 patients of both sexes, 18-60y, American Society of Anesthesiologist I or II and scheduled for elective single level lumbar laminectomy under general anaesthesia. All patients are randomly allocated into 3 equal groups: Control group (received a placebo capsule orally $1 \mathrm{~h}$ before induction of anesthesia and $5 \mathrm{ml}$ normal saline Intravenous (IV) before induction of anesthesia). Pregabalin group: Received a $150 \mathrm{mg}$ pregabalin capsule orally $1 \mathrm{~h}$ before induction of anesthesia and $5 \mathrm{ml}$ normal saline IV before induction of anesthesia and ketamine group: Received a placebo capsule orally $1 \mathrm{~h}$ before induction of anesthesia and $0.3 \mathrm{mg} / \mathrm{kg}$ ketamine in $5 \mathrm{ml}$ of normal saline syringe IV before induction of anesthesia. Visual Analogue Scale (VAS), Heart Rate (HR) \& Mean Arterial Pressure (MAP) were recorded at $30 \mathrm{~min}, 2 \mathrm{~h}, 4 \mathrm{~h}, 6 \mathrm{~h}, 12 \mathrm{~h}, 18 \mathrm{~h}$ and $24 \mathrm{~h}$ post-operative, the time (h) to first analgesic requirement, total dose of rescue analgesia (morphine) were recorded. Sedation scores \& complications were measured.
\end{abstract}

Results: Our results showed no significant difference as regard to age, sex, weight \& ASA physical status, but there was significant decrease in VAS. 1 st analgesic requirements $\&$ total dose of rescue analgesia in pregabalin group \& ketamine group as compared to control group with $(p<0.05) \&$ pregabalin group was superior to both groups as regard sedation score.

Conclusion: Pre-operative administration of oral pregabalin (1 50mg) 1h before surgery or IV ketamine at dose

Correspondence to: Dr. Ahmed G. Arakeeb,

The Department of Anesthesiology and Surgical Intensive Care, Faculty of Medicine, Tanta University
$(0.3 \mathrm{mg} / \mathrm{kg})$ at induction in patients undergoing elective singlelevel lumbar laminectomy significantly decreased postoperative pain, total opioid consumption as compared with control group without significant side effects.

Key Words: Preemptive analgesia-Pregabalin - Ketamine - Laminectomy.

\section{Introduction}

LUMBAR spinal stenosis is a narrowing of the spinal canal by surrounding bone and soft tissues that compromises neural structures [1]. 85\% of patients typically present with significant longterm symptoms of intermittent neurogenic claudication (radicular pain during walking or standing that resolves with lumbar flexion) [2].

$80 \%$ of patients undergoing surgical procedures experience post-operative pain [3]. Poor control of post-operative pain can lead to complications that delay discharge from hospital. Mild or severe pain after surgery can have a negative effect on the pulmonary system and cardiovascular system. Additionally, it can also prevent early mobilization and lead to reduced bladder and intestinal motility.

Administration of analgesic medication, before the actual onset of painful stimulus, is more effective than after the onset of painful stimulus. This is the principle of pre-emptive analgesia. Although it is often considered superior to other forms of analgesia [4]

Gabapentinoids (gabapentin and pregabalin) were first used as anti-epileptics but later on found to have anti-nociceptive effects. Pregabalin-a structural analogue to gamma-amino butyric acid which is an inhibitory neurotransmitter-has a better phar- 
macokinetic profile than gabapentin as it has more bioavailability $(90 \%)$ and more rapid absorption reaching its peak level after $1 \mathrm{~h}$. Pregabalin has a linear dose-dependent plasma concentration level in contrast to gabapentin [5]. Pregabalin half-life is 4.6-6.8h [6], in addition, it has no hepatic metabolism and has less drug interaction than gabapentin $\left[{ }^{7},{ }^{8}\right]$.

N-Methyl-D-Aspartate (NMDA) receptors have an important role in the pathophysiology of pain, as they are responsible for central sensitization and wind-up phenomenon. Ketamine, as a NMDA receptor antagonist, has been studied for control of post-operative pain, but the results were contradictory. Some studies proved the preemptive analgesic effect of low-dose ketamine $[\mathbf{9 , 1 0 ]}$, while others could not confirm this effect [11-13].

The aim of this study is to compare the efficacy of oral pregabalin versus IV low dose ketamine for post-operative pain management in patients undergoing elective single level lumbar laminectomy with primary outcome (VAS) and secondary outcome (1 st analgesic requirements \& total dose of rescue analgesia).

\section{Patients and Methods}

This prospective double-blinded randomized controlled trial was carried out at Tanta University Hospitals for one year from July 2017 to July 2018. After approval from the Institutional Ethical Committee and written informed consent was obtained from the participants. 105 patients of both sexes aged $18-60 y$, ASA physical status I or II and scheduled for elective single level lumbar laminectomy under General Anesthesia (GA) were enrolled. Every patient received an explanation to the purpose of the study and had a secret code number to ensure privacy to participants and confidentiality of data.

Exclusion criteria were refusal of the patient, contraindications or allergy for ketamine, pregabalin or morphine, pre-operative use of active alcohol or chronic usage of opioids, intake of any analgesics 48 hours before surgery, psychiatric illness and communication difficulties, and history of seizures.

An anesthesiologist not involved in the study prepared the drugs according to randomization. The patients and the staff involved in data collection were unaware of the group assignment. Randomization was performed using computer generated random numbers concealed in sealed envelopes indicating the group of assignment, a blinded nurse who didn't participate in the study or data collection, read the number contained in the envelope and made group assignment.

105 patients were randomly assigned to one of three groups: Control group (Group C: Received a placebo capsule orally $1 \mathrm{~h}$ before induction of anesthesia and $5 \mathrm{ml}$ normal saline Intravenous (IV) before induction of anesthesia. Pregabalin group (Group P): Received a 150mg pregabalin capsule orally $1 \mathrm{~h}$ before induction of anesthesia and $5 \mathrm{ml}$ normal saline IV before induction of anesthesia. Ketamine group (Group K): Received a placebo capsule orally $1 \mathrm{~h}$ before induction of anesthesia and $0.3 \mathrm{mg} / \mathrm{kg}$ ketamine in $5 \mathrm{ml}$ of normal saline syringe IV just before induction of anesthesia.

All patients were subjected to a careful history taking; complete physical examination and routine laboratory investigations were done. Patients fasted for 6 hours for solids, 4 hours for semisolids \& 2 hours for clear fluids. Visual Analogue Scale (VAS) was explained to the patients $\&$ all patients were well trained to use it.

On arrival to operating room, an IV line was established with $18 \mathrm{G}$ cannula in all patients in the non-operative side, standard monitoring was applied including ECG, pulse oximetry, noninvasive arterial blood pressure \& end tidal capnograghy.

\section{Anesthetic technique:}

After preoxygenation with $100 \%$ oxygen for $3 \mathrm{~min}$, general anesthesia was induced with fentanyl $1 \mu \mathrm{g} / \mathrm{kg} \mathrm{IV}$, propofol $2 \mathrm{mg} / \mathrm{kg}$ IV, endotracheal intubation was facilitated by using cis-atracurium as muscle relaxant in the dose of $0.15 \mathrm{mg} / \mathrm{kg}$ IV. Anesthesia was maintained with oxygen $50 \%$ in air and isoflurane $1.2 \%$. Patients were turned into prone position. Supplemental boluses of cisatracurium $0.03 \mathrm{mg} / \mathrm{kg}$ IV was administered as required maintaining muscle relaxation during surgery. Additional doses of fentanyl were given to maintain HR within $15 \%$ of the baseline value and systolic arterial blood pressure within $20 \%$ of the baseline value. The tidal volume and respiratory rate were adjusted to maintain end-tidal $\mathrm{CO} 2$ between 30 and $35 \mathrm{mmHg}$. At the end of surgery, inhalational anesthesia was discontinued. Muscle relaxation was reversed by IV neostigmine $0.05 \mathrm{mg}$ $/ \mathrm{kg}$ and atropine $0.01 \mathrm{mg} / \mathrm{kg}$ and then extubation was done when the patients were fully awake. Patients were transferred to Post-operative Anesthesia Care Unit (PACU) then discharged to ward after fulfillment of discharge criteria with modified Aldrete score (Table 1) above nine. 
Table (1): Modified Aldrete score.

\begin{tabular}{|c|c|c|c|}
\hline & 2 & 1 & 0 \\
\hline - Respiration & $\begin{array}{l}\text { - Able to take deep breathe and } \\
\text { cough }\end{array}$ & - Dyspnea/shallow breathing & - Apnea \\
\hline - $\mathrm{O}_{2}$ saturation & - Maintained $>92 \%$ on room air & $\begin{array}{l}\cdot \text { Need } \mathrm{O}_{2} \text { inhalation to be } \\
\text { maintained }>92 \% \text { on room air }\end{array}$ & $\begin{array}{l}\text { - Saturation }<90 \% \text { even with } \mathrm{O}_{2} \\
\text { inhalation }\end{array}$ \\
\hline - Consciousness & - Fully awake & -Arousable on calling & - Not responding \\
\hline - Circulation & $\begin{array}{l}\cdot \mathrm{ABP} \leq 20 \% \text { of the preanesthetic } \\
\text { level }\end{array}$ & $\begin{array}{l}\text { - ABP between } 20 \% \text { and } 49 \% \text { of } \\
\text { the preanesthetic level }\end{array}$ & $\begin{array}{l}\text { - } \mathrm{ABP} \geq 50 \% \text { of the preanesthetic } \\
\text { level }\end{array}$ \\
\hline - Activity & $\begin{array}{l}\text { - Able to move } 4 \text { extremities } \\
\text { voluntarily or on command }\end{array}$ & $\begin{array}{l}\text { - Able to move } 2 \text { extremities } \\
\text { voluntarily or on command }\end{array}$ & $\begin{array}{l}\text { - Able to move } 0 \text { extremities } \\
\text { voluntarily or on command }\end{array}$ \\
\hline
\end{tabular}

The following data were measured for each patient: Age, weight, sex and ASA physical status. Also, hemodynamic status (Heart Rate (HR), Mean Arterial Blood Pressure (MAP)) which were recorded at $30 \mathrm{~min}, 2 \mathrm{~h}, 4 \mathrm{~h}, 6 \mathrm{~h}, 12 \mathrm{~h}, 18 \mathrm{~h}$ and $24 \mathrm{~h}$ post-operative.

Post-operative pain was measured using VAS at $30 \mathrm{~min}, 2 \mathrm{~h}, 4 \mathrm{~h}, 6 \mathrm{~h}, 12 \mathrm{~h}, 18 \mathrm{~h}$ and $24 \mathrm{~h}$ postoperative. Onset of 1 st dose of rescue analgesia (which defined as the time from completion of surgery till the time for first request for analgesia), total dose of rescue analgesic consumed over $24 \mathrm{~h}$ post-operative (was maintained by $2 \mathrm{mg}$ morphine IV bolus if the body weight is less than $60 \mathrm{~kg}$ or $3 \mathrm{mg}$ if the body weight is more than $60 \mathrm{~kg}$, with 10 min lock out interval, repeated till the VAS is below 3 ) and number of patients received rescue analgesics were recorded. Sedation was recorded at $30 \mathrm{~min}, 2 \mathrm{~h}, 4 \mathrm{~h}, 6 \mathrm{~h}, 12 \mathrm{~h}, 18 \mathrm{~h}$ and $24 \mathrm{~h}$ postoperatively as follow: (Awake and alert $=0$, quietly awake $=1$, asleep but easily aroused $=2$, deep sleep $=3$ ). Incidence of any complications or side effects as post-operative vomiting (PONV), dizziness, visual disturbance, nightmares, and hallucinations was recorded up to $24 \mathrm{~h}$ after the surgery.

\section{Statistical analysis:}

The primary outcome in the present study was the pain intensity that was assessed with VAS. We assumed a difference of $2 \mathrm{~cm}$ in the VAS among groups with $80 \%$ power of the study and $95 \%$ confidence limit ( $\alpha$-error of 0.05 ) based on the results of a pilot study in our hospital. The sample size based on the previous criteria was found to be $>32$ patients in each group. We used 35 patients in each group to compensate for any possible dropout.

The statistical software SPSS V.16 (SPSS Inc., Chicago, IL, USA) was utilized for statistical analysis. Normality of data was checked with the Shapiro-Wilk test. The parametric data were ex- pressed as mean \pm SD and was analyzed utilizing student $t$-test. VAS score was analyzed among the studied groups utilizing the Mann-Whitney test. Categorical data were presented as patients' number or frequencies (\%) and were analyzed utilizing the Chi-square test or Fisher's exact test when appropriate. $p$-value $<0.05$ was considered significant.

\section{Results}

117 patients of both sexes were assessed for eligibility and 12 patients were excluded Fig. (1). There was no significant difference among the three groups as regards demographic data (age, weight, sex, ASA physical status), and side effects (nausea and vomiting) (Tables 2,3).

Table (2): Demographic data among the three studied groups.

\begin{tabular}{lllll}
\hline & $\begin{array}{c}\text { Group C } \\
(\mathrm{n}=35)\end{array}$ & $\begin{array}{c}\text { Group P } \\
(\mathrm{n}=35)\end{array}$ & $\begin{array}{c}\text { Group K } \\
(\mathrm{n}=35)\end{array}$ & $\begin{array}{c}p \text { - } \\
\text { value }\end{array}$ \\
\hline $\begin{array}{l}\text { Age (years): } \\
\quad \text { Range }\end{array}$ & $30-59$ & $33-60$ & $30-60$ & 0.988 \\
$\quad$ Mean \pm SD & $44 \pm 8$ & $47 \pm 8$ & $49 \pm 9$ & \\
Weight (kg): & & & & \\
$\quad$ Range & $63-110$ & $63-102$ & $62-98$ & 0.243 \\
$\quad$ Mean \pm SD & $82 \pm 13$ & $80 \pm 11$ & $78 \pm 9$ & \\
ASA: & & & & \\
$\quad$ I & $17(49 \%)$ & $22(63 \%)$ & $20(57 \%)$ & 0.489 \\
II & $18(51 \%)$ & $13(37 \%)$ & $15(43 \%)$ & \\
Sex: & & & & \\
$\quad$ Male & $22(63 \%)$ & $15(43 \%)$ & $19(54 \%)$ & 0.243 \\
Female & $13(13 \%)$ & $20(57 \%)$ & $16(46 \%)$ & \\
\hline
\end{tabular}

Table (3): Adverse effects in the three groups.

\begin{tabular}{lcccc}
\hline & $\begin{array}{c}\text { Group C } \\
(\mathrm{n}=35)\end{array}$ & $\begin{array}{c}\text { Group P } \\
(\mathrm{n}=35)\end{array}$ & $\begin{array}{c}\text { Group K } \\
(\mathrm{n}=35)\end{array}$ & $\begin{array}{c}p \text { - } \\
\text { value }\end{array}$ \\
\hline Nausea & $9(26 \%)$ & $8(23 \%)$ & $4(11 \%)$ & 0.29 \\
Vomiting & $5(14 \%)$ & $4(11 \%)$ & $2(6 \%)$ & 0.49 \\
\hline
\end{tabular}




\begin{tabular}{|c|c|c|}
\hline \multirow{2}{*}{ Allocation } & & $\begin{array}{l}\text { Excluded }(n=12) \\
\text { - Not meeting inclusion criteria }(n=9) \\
\text { - Uncontrolled hypertensive patients }(n=5) \\
\text { - Allergy to morphine }(n=2) \\
\text { - Intake of analgesics within } 48 \text { hours before surgery }(n=2) \\
\text { - Patient refusal }(n=3)\end{array}$ \\
\hline & Randomized (n=105) & \\
\hline $\begin{array}{l}\text { Control group (Group C) }(\mathbf{n}=\mathbf{3 5}) \text { : } \\
\text { Allocated to receive a placebo } \\
\text { capsule orally } 1 \mathrm{~h} \text { before induction of } \\
\text { anesthesia and } 5 \mathrm{ml} \text { normal saline IV } \\
\text { before induction of anesthesia. }\end{array}$ & $\begin{array}{l}\text { Pregabalin group (Group P) }(\mathbf{n}=\mathbf{3 5}) \text { : } \\
\text { Allocated to receive a } 150 \mathrm{mg} \\
\text { pregabalin capsule orally } 1 \mathrm{~h} \text { before } \\
\text { induction of anesthesia and } 5 \mathrm{ml} \text { normal } \\
\text { saline IV before induction of anesthesia. }\end{array}$ & $\begin{array}{l}\text { Ketamine group (Group K) }(\mathbf{n}=\mathbf{3 5}) \text { : } \\
\text { Allocated to receive a placebo capsule } \\
\text { orally } 1 \mathrm{~h} \text { before induction of anesthesia and } \\
0.3 \mathrm{mg} / \mathrm{kg} \text { ketamine in } 5 \mathrm{ml} \text { of normal saline } \\
\text { syringe IV before induction of anesthesia. }\end{array}$ \\
\hline & Follow-Up & \\
\hline $\begin{array}{l}\text { - Patients after } 30 \mathrm{~min} \text {. and subsequently } \\
\text { after } 2,4,6,12,18 \text { and } 24 \mathrm{~h} \text { after the } \\
\text { emergence from anesthesia. } \\
\text { - No drop-out. }\end{array}$ & $\begin{array}{l}\text { - Patients after } 30 \mathrm{~min} \text {. and subsequently } \\
\text { after } 2,4,6,12,18 \text { and } 24 \mathrm{~h} \text { after the } \\
\text { emergence from anesthesia. } \\
\text { - No drop-out. }\end{array}$ & $\begin{array}{l}\text { - Patients after } 30 \mathrm{~min} \text {. and subsequently } \\
\text { after } 2,4,6,12,18 \text { and } 24 \mathrm{~h} \text { after the } \\
\text { emergence from anesthesia. } \\
\text { - No drop-out. }\end{array}$ \\
\hline & Analysis & \\
\hline & $\downarrow$ & $\downarrow$ \\
\hline $\begin{array}{l}\text { - The results are tabulated and satistically } \\
\text { analyzed }(\mathrm{n}=35) \text {. } \\
\text { - No excluded cases. }\end{array}$ & $\begin{array}{l}\text { - The results are tabulated and satistically } \\
\text { analyzed }(n=35) \text {. } \\
\text { - No excluded cases. }\end{array}$ & $\begin{array}{l}\text { - The results are tabulated and satistically } \\
\text { analyzed }(\mathrm{n}=35) \text {. } \\
\text { - No excluded cases. }\end{array}$ \\
\hline
\end{tabular}

Fig. (1): Patient flowchart of the study protocol.

There was significant decrease in HR in Group (P) compared to Group (C) with $(p<0.05)$ and in Group (P) compared to Group (K) at 30min and 2 hours post-operatively with $(p<0.001,0.024)$ respectively. At $30 \mathrm{~min}$ post-operatively, there was significant decrease in Group $(\mathrm{K})$ compared to Group (C) with $(p=0.041)$. While there is insignificant difference in HR among the three groups at other time points Fig. (2).

MAP at $30 \mathrm{~min}$ and $2 \mathrm{~h}$ post-operative showed significant decrease in Group (P) compared to Group (C) with $(p<0.05)$. MAP at 30 min postoperative showed significant decrease in Group (P) compared to Group (K) and in Group (K) compared to Group $(\mathrm{C})$ with $(p<0.05)$ while there was insignificant difference in MAP among the three groups at other time points Fig. (3).

VAS showed significant decrease in Group (P) compared to Group (C) at 30min, 2, 12 and 24h post-operatively with $(p=0.001,0.033,0.001$, $0.008^{*}$ ) respectively. At 30min, 2, 6 and 12 hours post-operatively, there is significant decrease in
VAS in Group (K) compared to Group (C) with $(p=0.001,0.017,0.016,0.002)$. At $30 \mathrm{~min}$ postoperatively, there was significant decrease in Group (P) compared to Group $(\mathrm{K})$ with $(p=0.001)$. At 4 and $18 \mathrm{~h}$ post-operatively, there was insignificant difference among the three groups Fig. (4).

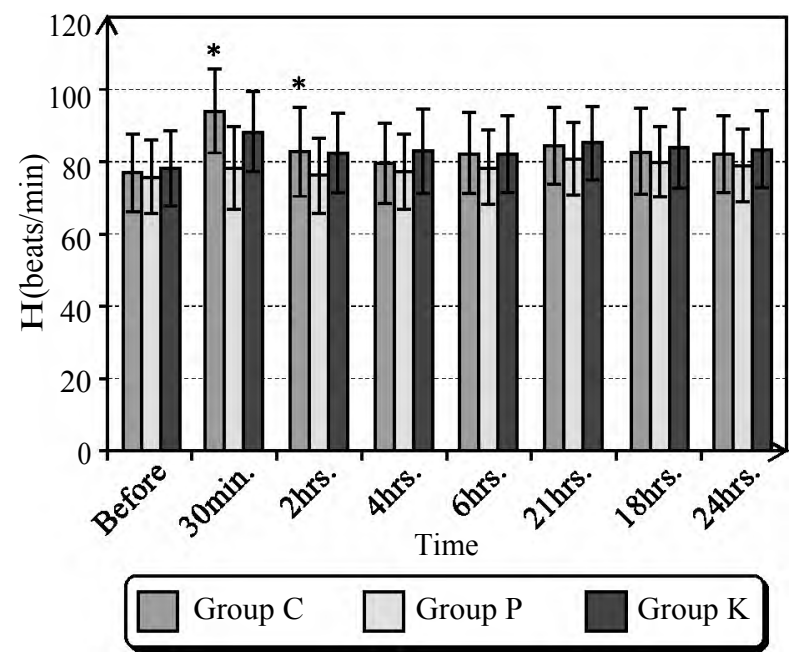

Fig. (2): Heart Rate (HR) changes in the studied groups. 


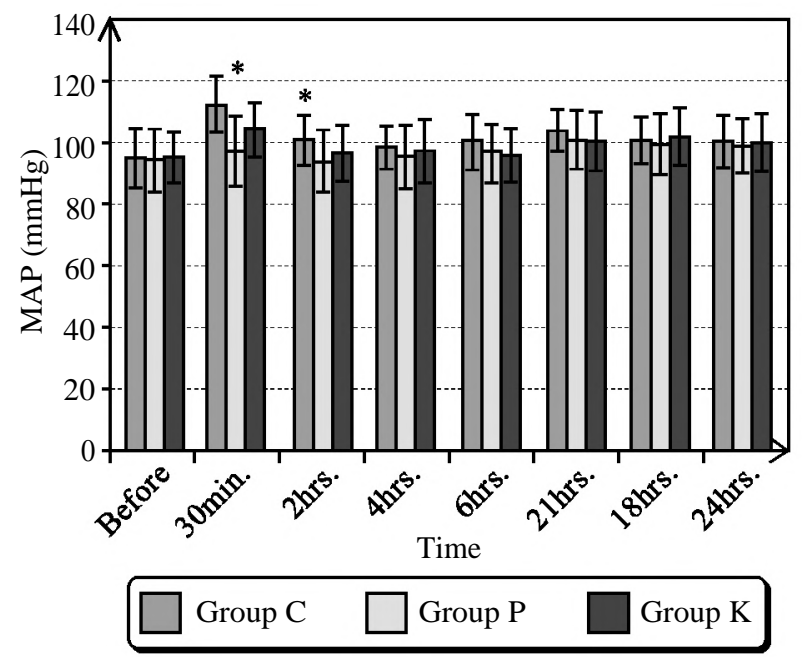

Fig. (3): Mean arterial blood pressure (MAP) changes in the studied groups.

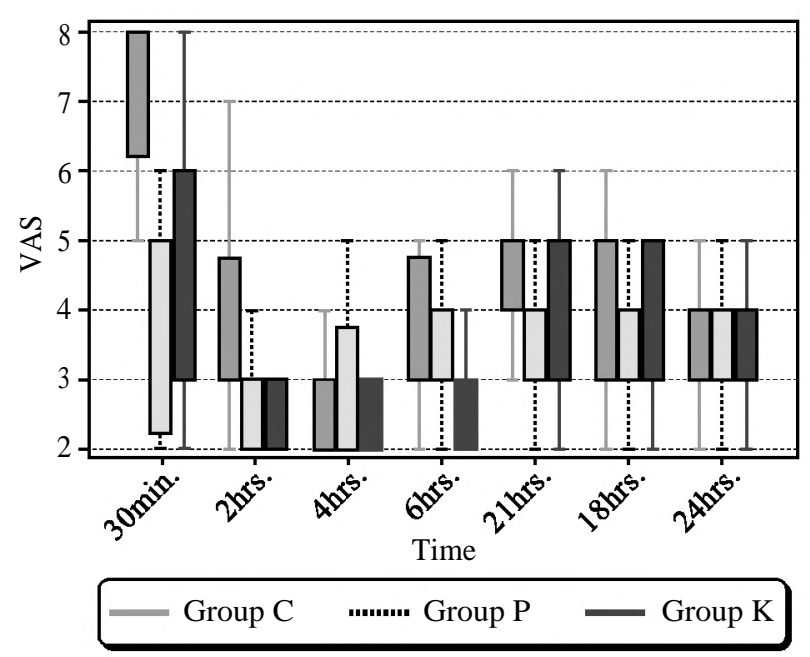

Fig. (4): Visual Analogue Scale (VAS) changes in the studied groups.

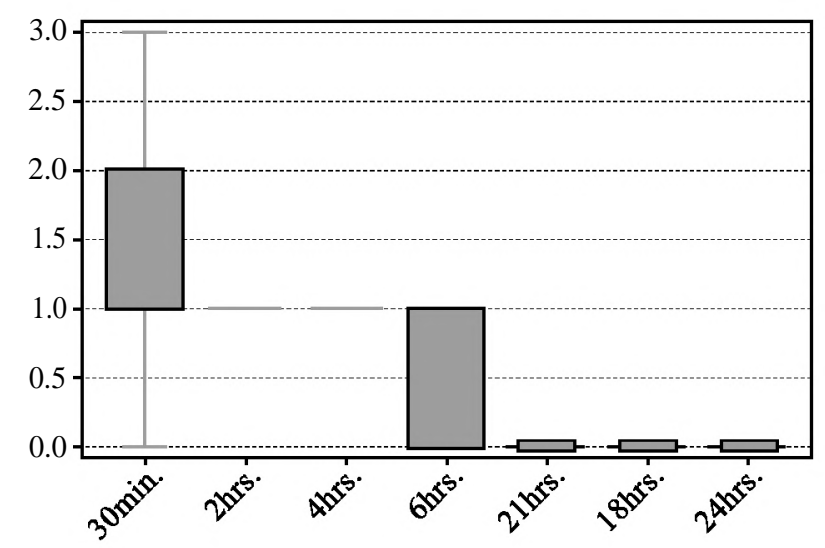

Fig. (5): Sedation score in the three studied groups.

There was a significant prolongation in the time of first analgesic requirement in the pregabalin and ketamine groups compared to control group with $(p<0.05)$. In addition, there was a significant prolongation in the pregabalin group compared to ketamine group with $(p=0.018)$ Fig. (6).

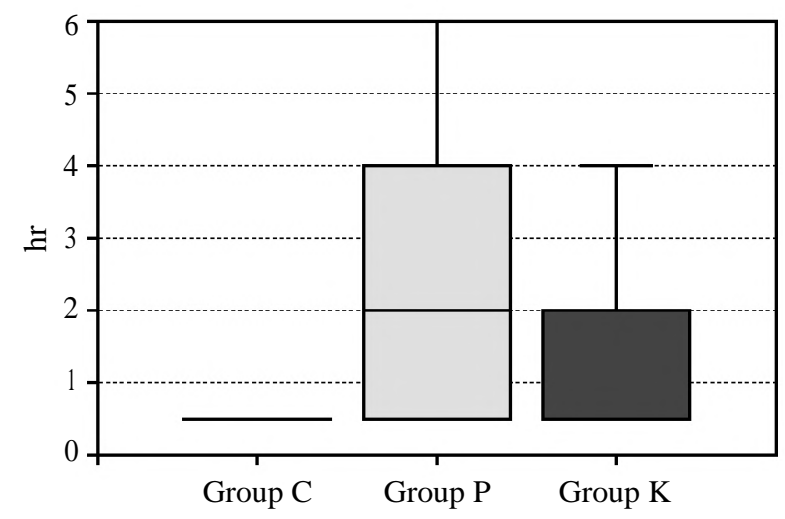

Fig. (6): 1 st time rescue analgesia requirement in three groups.

The total morphine consumption was decreased significantly in Group $(\mathrm{P})$ and Group $(\mathrm{K})$ compared to Group (C) with $(p<0.05)$, while there was insignificant difference between Group (P) and Group (K) $(p=0.337)$ Fig. (7).

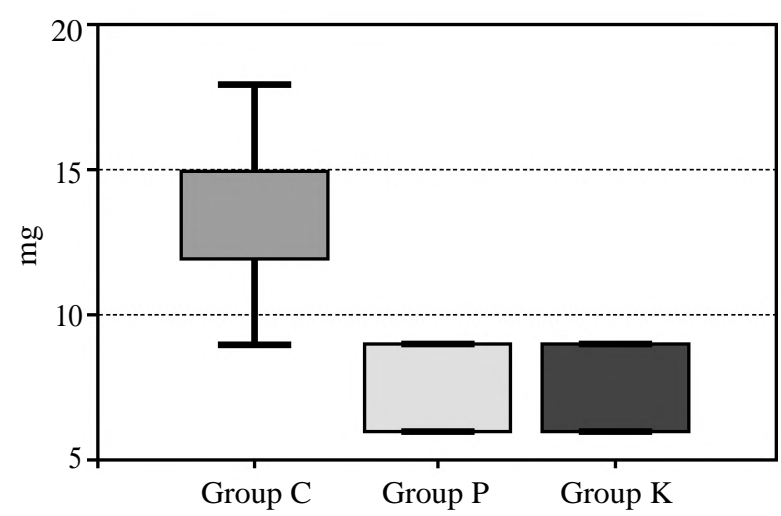

Fig. (7): Total rescue analgesia consumption in the three groups.

Sedation score showed significant increase in Group $(\mathrm{P})$ compared to the other groups at $0.5 \mathrm{~h}$, $2 \mathrm{~h}, 4 \mathrm{~h}$ and $6 \mathrm{~h}$ post-operatively with $(p<0.05)$, while there was insignificant difference among the three groups at any time denoting pregabalin has sedative effect of benefit in reducing HR and MAP postoperatively.

There was no reported visual disturbance in all the three groups with insignificant difference in nausea \& vomiting among three groups ( $p=0.29$, 0.49 ) respectively (Table 3 ).

\section{Discussion}

Subanesthetic dose of ketamine may be used to prevent acute and chronic pain [14]. Pregabalin has demonstrated better efficacy against acute somatic pain than visceral pain, [15] and has been 
beneficial in patients with severe post-operative pain [16].

There was a significant lower pain scores in pregabalin and ketamine groups in comparison with the control group at 30min, 2, 6, 12, 18 and $24 \mathrm{~h}$ post-operatively. While, there was insignificant difference between ketamine group and pregabalin group in pain scores at any time points.

Ketamine's analgesic properties in acute pain likely derived from its reversible antagonism of NMDA receptor, although it exerts effects on pi-opioid, muscarinic, monoaminergic receptors, GABA receptors. Ketamine when administrated in sub-anesthetic doses prevents the development of central sensitization, hyperalgesia and opioid resistance [17]

Our findings were in concordance with the study carried out by Rogers et al., [18] who found that a Subanesthetic infusion of ketamine $(0.71 \mathrm{mg} /$ $\mathrm{kg}$ per hour) significantly reduced pain scores. Besides that, Behdad et al., [9] found that the ketamine lowered the VAS score significantly after appendectomy. Also, Parikh et al., [19] reported that small dose ketamine administration during renal surgery lowered the VAS significantly during 1 st 12 hours post-operatively.

Also, the meta-analytic study carried out by Pendi et al., [20] on 14 RCTs assessing the analgesic effect of ketamine in spine surgery, sub anesthetic ketamine was associated with lower post-operative pain scores.

The analgesic effect of pregabalin is probably the same as gabapentin. Gabapentinoids bind to the $\alpha_{2} \zeta$ subunit of voltage-gated calcium channels and reduce the release of several neurotransmitters like glutamate, noradrenaline, calcitonin generelated peptide, and substance $P$, resulting in analgesic effects [21].

Our findings were in agreement with the study carried out by Hills et al., [22], pregabalin $300 \mathrm{mg}$ group had significantly lower VAS scores compared to the other groups.

Also, Kumar et al., [7] who studied the effect of pregabalin $150 \mathrm{mg}$ orally 1 hour before anesthetic induction on post-operative pain management in patients undergoing elective decompressive lumbar laminectomy, pain scores was significantly decreased in patients who received pregabalin till 6 hours after emergence from anesthesia.

In the present study, with respect post-operative analgesic consumption, there was significant de- crease in its values in ketamine and pregabalin group compared to control group with no significant difference between ketamine and pregabalin groups.

Bells et al., [23] reported that treatment with ketamine reduced 24 hours patient controlled analgesia morphine consumption. Also, Loftus et al., [24] reported that the total morphine consumption was reduced significantly in ketamine group 24 hours after the procedure.

Besides that, Lashowski et al., [25] in their metaanalytic study demonstrated an opioid sparing effect with ketamine treatment. The upper abdominal and thoracic procedures showed the greatest decrease in opioid use. Orthopedic (limb and spine), intra-abdominal and lower abdominal surgery showed decreased opioid use with the use of ketamine.

In addition, the same was demonstrated by Kaur et al., [26] was confirmed by the results of Pendi et al., [20] in their meta-analytic study, they found that ketamine group exhibited less morphine equivalent consumption at 4, 8, 12 and 24 hours following surgery following surgery.

The results of the pregabalin group in our present study is supported by the results of Reuben et al., [16] who found reduced opioid use in the pregabalin group compared to control group.

Also, Zhang et al., [27] reported a significant decreased cumulative opioid consumption at 24 hours with pregabalin in the meta-analytic study.

Moreover, Kim et al., [28] found that the amount of PCA volume infused until hours after surgery and the frequency of rescue analgesic administrated 6 and 24 hours after surgery were significantly reduced in pregabalin $150 \mathrm{mg}$ group compared to control group.

And, Kumar et al., [7] reported significant decrease in the rescue analgesic consumption (fentanyl and diclofenac) in the 1 st 6 hours postoperatively in pregabalin group.

In addition, Mahran and Hassan [29] found that the use of pregabalin and ketamine reduced the total post-operative morphine consumption. However, there was no significant difference between ketamine and pregabalin groups in opioid requirement.

Regarding the time of first analgesic requirement in the present study, there was a significant prolongation in the time of first analgesic requirement in the pregabalin and ketamine groups com- 
pared to control group. Also, there was a significant prolongation in the pregabalin group compared to ketamine group.

With respect to the results of ketamine groups in the present study, our results were supported with the meta-analytic study of Lashowski et al., [25] demonstrated a significant prolongation in the time of first analgesic requirement in the ketamine groups compared to control group.

And, Parikh et al., [19] reported that the time of first analgesic demand was longer in patients of the ketamine groups compared to control group.

There was hemodynamic stability in the three studied groups. The results of the ketamine group in our present study is supported by the results of Parikh et al., [19] who reported no hemodynamic disturbances in patients who received low dose ketamine compared to control group.

And, Barreveld et al., [30] observed that ketamine infusion at a dose of $0.2 \mathrm{mg} / \mathrm{kg} / \mathrm{h}$ was not associated with adverse hemodynamic changes for post-operative pain in patients taking opioids for chronic pain.

Kumar et al., [7] who found no significant difference in HR and MAP till 6 hours postoperatively (their follow-up period) among the pregabalin (100 and 150mg) and control groups.

Concerning the sedation in the present study, there was no case of sedation in the ketamine group. While, in the pregabalin group one patient had a score of 3 which decreased to 1 at 6 hours. 23 patients had a score of 1 and 11 patients had a score of 2. At 12 hours, all patients had a score of zero.

Reuben et al., [16] reported few occurrences of sedation with the pregabalin.

Bornemann-Cimenti et al., [31] found that patients in the pregabalin group were more sedated but there were no cases of severe sedation $(>2)$ in the pregabalin group.

Also, Mahran and Hassan [29] found that only one patient in the pregabalin group had a sedation score $>2$ with no significant difference among their three studied groups.

While, Kim et al., [28] found no significant difference in the incidence of sedation among patients who received pregabalin (75 or $150 \mathrm{mg}$ ) and the control group.
Regarding the dizziness and visual disturbance in the present study, there was no reported visual disturbance in all the three groups.

Our results in the ketamine group were in agreement with those of Loftus et al., [24], Behdad et al., [9], Parikh et al., [19], Kaur et al., [26], Perelló et al., [32] and Pendi et al., [20] who reported that none of the adverse effects associated with delirium (unpleasant dreams, hallucinations, psychomimetic events and dysphoria), nightmares or diplopia achieved significance in patients taking ketamine.

On the other hand, Lashowski et al., [25] demonstrated that most of the studies included in their meta-analytic study reported (neuro-psychiatric disturbance, unpleasant dreams, diplopia, nystagmus or dysphoria) in the groups treated with ketamine. However, most individual articles in their study reported these effects as event counts rather than severity weren't significant and commented that the psychological side effects were well tolerated.

Our results in the pregabalin group are in agreement with those of Mahran and Hassan [29] and Gupta et al., [33] who found no significant difference in the incidence of dizziness or visual disturbance in their study group compared to the control group.

While, the meta-analytic study by Zhang et al., [27] reported that the patients who received pregabalin were at high risk of visual disturbance. We attribute this difference with our results to the difference in the dose of pregabalin (some studies use large bolus dose $>300 \mathrm{mg}$ or continuous infusion) and the time of administration (some studies give pregabalin in post-operative period in addition to the pre-operative doses).

With respect to nausea and vomiting in the present study, there was insignificant difference in nausea $\&$ vomiting among three groups.

Our results in the ketamine group are in agreement with those of Bells et al., [23], Lashowski et al., [25], Parikh et al., [19], Kaur et al., [26], Perelló et al., [32] and Pendi et al., [20]. They observed no significant difference between groups in the incidence of nausea and vomiting.

Also, our results in the pregabalin group are supported by Jokela et al., [34], Zhang et al., [27], Kim et al., [28], Bornemann-Cimenti et al., [31], and Mahran and Hassan [29], all of them reported no significant difference between pregabalin and control groups in their study. 


\section{Conclusion:}

Pre-operative administration of oral pregabalin $(150 \mathrm{mg}) 1 \mathrm{~h}$ before surgery or IV ketamine at dose $(0.3 \mathrm{mg} / \mathrm{kg})$ at induction in patients undergoing elective single-level lumbar laminectomy significantly decreased post-operative pain, total opioid consumption as compared with control group without significant side effects.

\section{Conflicts of interest: Nil.} role.

Authors' contributions: All authors had equal

\section{References}

1- ISHIMOTO Y., YOSHIMURA N., MURAKI S., YAMADA H., NAGATA K., HASHIZUME H., et al.: Associations between radiographic lumbar spinal stenosis and clinical symptoms in the general population: The Wakayama Spine Study. Osteoarthritis Cartilage, 21 (6): 783-8, 2013.

2- BENOIST M.: The natural history of lumbar degenerative spinal stenosis. Joint Bone Spine, 69 (5): 450-7, 2002.

3- APFELBAUM J.L., CHEN C., MEHTA S.S. and GAN T.J.: Post-operative pain experience: Results from a national survey suggest post-operative pain continues to be undermanaged. Anesth. Analg., 97 (2): 534-40, 2003.

4- YU L., RAN B., LI M. and SHI Z.: Gabapentin and pregabalin in the management of post-operative pain after lumbar spinal surgery: A systematic review and metaanalysis. Spine, 38 (22): 1947-52, 2013.

5- GAJRAJ N.M.: Pregabalin: Its pharmacology and use in pain management. Anesth. Analg., 105 (6): 1805-15, 2007.

6- FRAMPTON J.E. and FOSTER R.H.: Pregabalin: In the treatment of postherpetic neuralgia. Drugs, 65 (1): 1118, 2005.

7- KUMAR K.P., KULKARNI D.K., GURAJALA I. and GOPINATH R.: Pregabalin versus tramadol for postoperative pain management in patients undergoing lumbar laminectomy: A randomized, double-blinded, placebocontrolled study. J. Pain Res., 6: 471, 2013.

8- BEN-MENACHEM E.: Pregabalin pharmacology and its relevance to clinical practice. Epilepsia, 45: 13-8, 2004.

9- BEHDAD A., HOSSEINPOUR M. and KHORASANI P.: Preemptive use of ketamine on post-operative pain of appendectomy. Korean J. Pain, 24 (3): 137-40, 2011.

10- MENKITI I., DESALU I. and KUSHIMO O.: Low-dose intravenous ketamine improves post-operative analgesia after caesarean delivery with spinal bupivacaine in African parturients. Int. J. Obstet. Anesth., 21 (3): 217-21, 2012.

11- HAN S.Y., JIN H.C., YANG W.D., LEE J.H., CHO S.H., CHAE W.S., et al.: The effect of low-dose ketamine on post-caesarean delivery analgesia after spinal anesthesia. Kore Pan Jain, 26 (3): 270-6, 2013.

12- BAUCHAT J., HIGGINS N., WOJCIECHOWSKI K., McCARTHY R., TOLEDO P. and WONG C.: Low-dose ketamine with multimodal postcesarean delivery analgesia:
A randomized controlled trial. Int. J. Obstet. Anesth., 20 (1): 3-9, 2011.

13- REZA F.M., ZAHRA F., ESMAEEL F. and HOSSEIN A.: Preemptive analgesic effect of ketamine in patients undergoing elective cesarean section. Clini. J. Pain, 26 (3): 223-6, 2010.

14- NIESTERS M., MARTINI C. and DAHAN A.: Ketamine for chronic pain: Risks and benefits. Br. J. Clin. Pharmacol., 77 (2): 357-67, 2014.

15- WHITE P.F., TUFANOGULLARI B., TAYLOR J. and KLEIN K.: The effect of pregabalin on pre-operative anxiety and sedation levels: A dose-ranging study. Anesth. Analg., 108 (4): 1140-5, 2009.

16- REUBEN S.S., BUVANENDRAN A., KROIN J.S. and RAGHUNATHAN K.: The analgesic efficacy of celecox$\mathrm{ib}$, pregabalin, and their combination for spinal fusion surgery. Anesth. Analg., 103 (5): 1271-7, 2006.

17- MAHER D.P., CHEN L. and MAO J.: Intravenous ketamine infusions for neuropathic pain management: A promising therapy in need of optimization. Anesth. Analg., 124 (2): 661-74, 2017.

18- ROGERS R., WISE R.G., PAINTER D.J., LONGE S.E. and TRACEY I.: An investigation to dissociate the analgesic and anesthetic properties of ketamine using functional magnetic resonance imaging. Anesthesiology, 100 (2): 292-301, 2004

19- PARIKH B., MALIWAD J. and SHAH V.R.: Preventive analgesia: Effect of small dose of ketamine on morphine requirement after renal surgery. J. Anaesthesiol. Clin. Pharmacol., 27 (4): 485-8, 2011.

20- PENDI A., FIELD R., FARHAN S.D., EICHLER M. and BEDERMAN S.S.: Perioperative ketamine for analgesia in spine surgery: A meta-analysis of randomized controlled trials. Spine, 43 (5): 299-307,2018.

21- KONG V. and IRWIN M.: Gabapentin: A multimodal perioperative drug? Br. J. Anaesth., 99 (6): 775-86, 2007.

22- HILL C., BALKENOHL M., THOMAS D., WALKER R., MATHE H. and MURRAY G.: Pregabalin in patients with post-operative dental pain. Eur. J. Pain, 5 (2): 11924, 2001.

23- BELL R., DAHL J., MOORE R. and KALSO E.: Perioperative ketamine for acute post-operative pain: A quantitative and qualitative systematic review (Cochrane review). Acta Anaesthesiol. Scand., 49 (10): 1405-28, 2005.

24- LOFTUS R.W., YEAGER M.P., CLARK J.A., BROWN J.R., ABDU W.A., SENGUPTA D.K., et al.: Intraoperative ketamine reduces perioperative opiate consumption in opiate-dependent patients with chronic back pain undergoing back surgery. Anesthesiology, 113 (3): 639-46, 2010.

25- LASKOWSKI K., STIRLING A., McKAY W.P. and LIM H.J.: A systematic review of intravenous ketamine for post-operative analgesia. Can. J. Anaesth., 58 (10): 91123, 2011.

26- KAUR S., SAROA R. and AGGARWAL S.: Effect of intraoperative infusion of low-dose ketamine on management of post-operative analgesia. J. Nat. Sc. Biol. Med., 6 (2): 378-82, 2015. 
27- ZHANG J., HO K.Y. and WANG Y.: Efficacy of pregabalin in acute post-operative pain: A meta-analysis. Br. J. Anaesth., 106 (4): 454-62, 2011.

28- KIM J.C., CHOI Y.S., KIM K.N., SHIM J.K., LEE J.Y. and KWAK Y.L.: Effective dose of peri-operative oral pregabalin as an adjunct to multimodal analgesic regimen in lumbar spinal fusion surgery. Spine, 36 (6): 428-33, 2011.

29- MAHRAN E. and HASSAN M.E.: Comparison of pregabalin versus ketamine in post-operative pain management in breast cancer surgery. Saudi J. Anaesth., 9 (3): 253-7, 2015.

30- BARREVELD A.M., CORRELL D.J., LIU X., MAX B., McGOWAN J.A., SHOVEL L., et al.: Ketamine decreases post-operative pain scores in patients taking opioids for chronic pain: Results of a prospective, randomized, doubleblind study. Pain Med., 14 (6): 925-34, 2013.

31- BORNEMANN-CIMENTI H., LEDERER A., WEJBORA
M., MICHAELI K., KERN-PIRSCH C., ARCHAN S., et al.: Pre-operative pregabalin administration significantly reduces post-operative opioid consumption and mechanical hyperalgesia after transperitoneal nephrectomy. Br. J. Anaesth., 108 (5): 845-9, 2012.

32- PERELLÓ M., ARTÉS D., PASCUETS C., ESTEBAN E. and BATLLE A.M.E.: Prolonged perioperative lowdose ketamine does not improve short and long-term outcomes after pediatric idiopathic scoliosis surgery. Spine, 42 (5): 304-12, 2017.

33- GUPTA P., SAXENA A. and CHAUDHARY L.: Effect of pregabalin premedication on the requirement of anesthetic and analgesic drugs in laparoscopic cholecystectomy: Randomized comparison of two doses. Anesth. Essays. Res., 11 (2): 330-3, 2017.

34- JOKELA R., AHONEN J., TALLGREN M., HAANPÄÄ M. and KORTTILA K.: A randomized controlled trial of perioperative administration of pregabalin for pain after laparoscopic hysterectomy. Pain, 134 (1-2): 106-12, 2008.

\section{دراسة مقارنة بين البريجابالين عن طريق الفم وجرعة صغيرة من الكيتامين

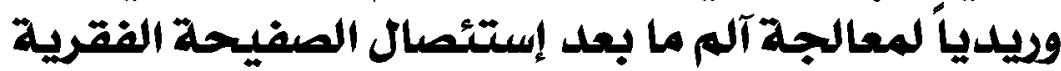

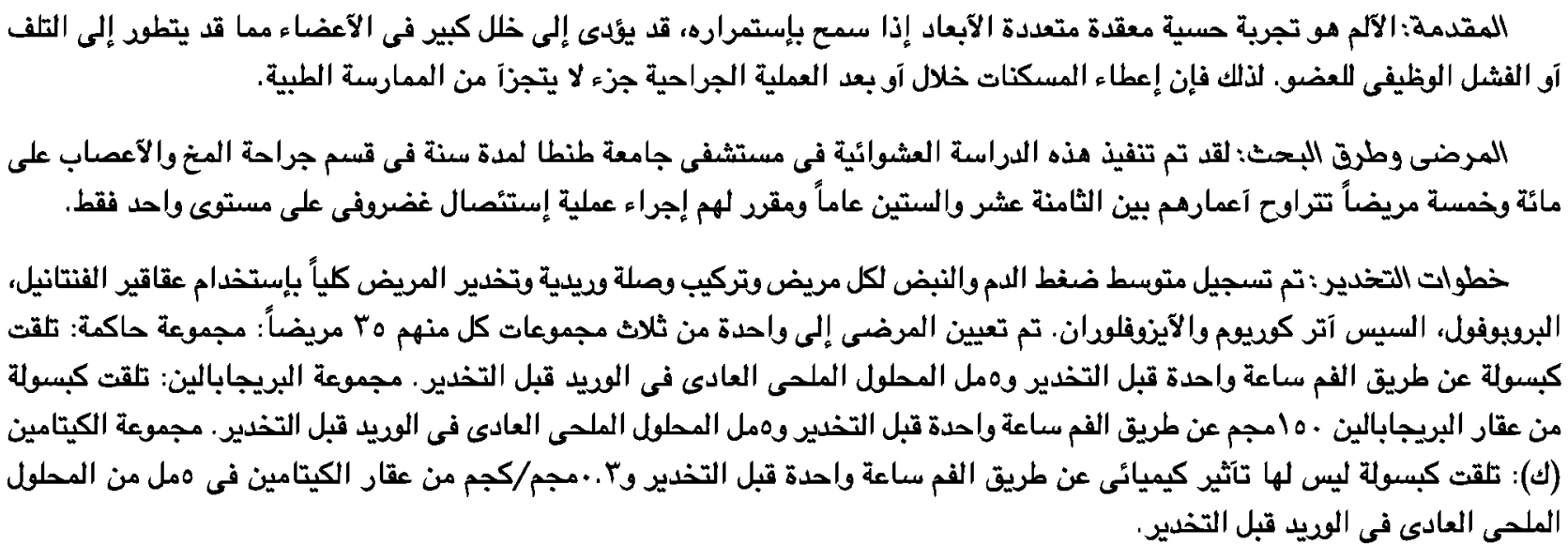

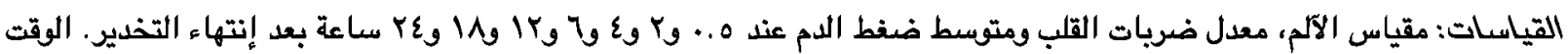

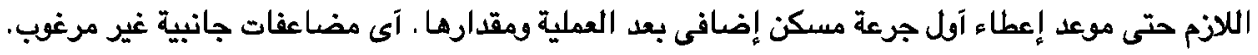

الملخص: آظهرت النتائج عدم وجو فرق بين عقار البريجابالين • مالمجم وعقار الكيتامين (ب . .مجم/كجم) فيما يتعلق بالبيانات الديموغرافية

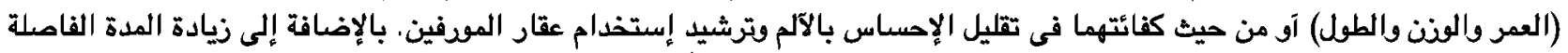

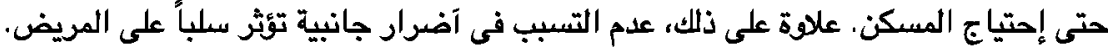

